Polish Journal of Microbiology

2013, Vol. 62, No 1, 59-66

ORIGINAL PAPER

\title{
Pathogenicity of Some Fusarium Species Associated with Superficial Blemishes of Potato Tubers
}

\author{
RUKAIA M. GASHGARI ${ }^{1}$ and YOUSSUF A. GHERBAWY ${ }^{2,3 *}$ \\ ${ }^{1}$ Science College, King Abdulaziz University, Jeddah, Saudi Arabia \\ ${ }^{2}$ Botany Department, Faculty of Science, South Valley University, Qena, Egypt \\ ${ }^{3}$ Biological Sciences Department, Faculty of Science, Taif University, Taif, Saudi Arabia
}

Received 19 April 2012, revised 10 September 2012, accepted 18 September 2012

Abstract

As an organ for reserve and propagation, the tuber grows underground and is in contact with soil-borne microorganisms, making it potentially exposed to blemishes. Therefore, the objective of this study was the possibility of using some modern methods of molecular diagnostics and detection of the presence of fungal contaminants in potato blemishes in Al-Qasim (Saudi Arabia). Polygonal lesions were the most observed blemish type in the collected samples. One hundred and sixty isolates were recovered from different types of blemishes obtained in this study. Fusarium, Penicillium, Ilyonectria, Alternaria and Rhizoctonia were the most common genera collected from different blemish types. Using ITS region sequencing, all collected fungi were identified at the species level. All Fusarium strains collected during this study were used to detect their pathogenicity against potato tubers. This is the first comprehensive report on the identification of major pathogenic fungi isolated from potato tuber blemishes in Saudi Arabia.

Ke y wo rds: Fusarium spp., Dry rot, ITS regions, potato tuber blemishes in Saudi Arabia

\section{Introduction}

There are literally hundreds of potato producers in the Kingdom of Saudi Arabia (KSA) comprising potato production units of all sizes and capabilities, growing many varieties for sale mainly to the wholesale markets. Over $75 \%$ of the total potato production in the Kingdom comes from small farmers distributed in different regions, and who supply local wholesale markets. Worldwide about 40 soil-borne diseases affect potato and cause severe damage especially on tubers, the economically most important part of the plant. Soil-borne diseases affecting potato crop can be divided into two groups depending on symptoms: symptoms damaging tubers and those damaging other parts of the plant (Gudmestad etal., 2007). Among diseases affecting tubers, symptoms can be divided into three categories: galls, blemishes and rots. Blemishes affect only the tuber skin, but they became economically important since consumers' habits have changed and tubers are washed before selling (Fiers et al., 2010).

Blemishes or superficial alterations affect only the tuber skin, without affecting the taste or the nutritional properties. However, they have a negative cosmetic effect on the tubers and destroy the integrity of the natural barrier of the skin, forming an entry point for pathogenic microorganisms (Fiers et al., 2010). Moreover, it has been shown that skin visual appearance is the most important factor influencing consumer behavior in fresh potato purchase. Economical data about such potential losses are difficult to estimate, but all potato sectors, i.e. seed, ware, and processing are affected. Potato tubers can show a large range of superficial blemishes. These blemishes may result from a pathogen attack or unfavourable environmental factors. When their causes are known, and the Koch's postulates have been fulfilled, these blemishes are called typical blemishes (Fiers et al., 2010). By contrast, the blemishes for which the causal agent has not been clearly identified are called atypical blemishes (Fiers et al., 2010). Atypical blemishes frequently observed in ware potato production are the atypical corky blemishes, especially polygonal lesions and corky spots (Fiers et al., 2010).

Several Fusarium spp. cause potato (Solanum tuberosum L.) seed piece decay, plant wilt and tuber dry rot in storage, leading to losses in crop yield and quality (Secor and Salas, 2001). Fusarium dry rot is caused by several species including Fusarium sambucinum Fuckel,

* Corresponding author: Y.A. Gherbawy, Biological Sciences Department Faculty of Science Taif University; Taif 888, Saudi Arabia; e-mail: youssufgherbawy@yahoo.com 
Fusarium culmorum (W.G. Smith) Sacc. and Fusarium oxysporum Schlecht, under field and storage conditions (Boyd, 1972; Schisler and Slininger, 1994). Crop losses attributed to the dry rot have been estimated to average $6 \%$, with losses up to $25 \%$ reported (Chelkowski, 1989). In addition to destroying tuber tissues, Fusarium spp. can produce toxins that have been implicated in mycotoxicoses of humans and animals (Senter et al., 1991; Schisler et al., 1997). F. sambucinum, Fusarium solani(Mart.) Sacc., F.culmorum and F. oxysporum are reported as common causes of dry rot of potatoes in Turkey, resulting in partial or almost complete loss of stored commercial potatoes varieties (Eken et al., 2000). Several Fusarium spp. cause potato seed piece decay, plant wilt and tuber dry rot in storage, leading to losses in crop yield and quality (Secor and Salas, 2001). In North America and parts of Europe, Fusarium sambucinum Fuckel is considered to be the most significant causal agent of tuber dry rot (Tivoli et al., 1986; Secor and Salas, 2001), whereas in the UK, F. coeruleum (Libert) Sacc. is more prevalent (Hide et al., 1992). In some instances, F. avenaceum (Fr.) Sacc. has also been implicated as the causal agent of tuber dry rot (Hide et al., 1992; Satyaprasad et al., 1997).

Rapid detection of plant parasitic pathogens enables to set up adapted control measures and to avoid disease expansion and yield losses, even if the infestation level is low. Molecular biology based-diagnosis and detection methods are expected to complement classical diagnosis. The most developed detection methods are based on polymerase chain reaction (PCR), which amplify DNA regions specific of the pathogen of interest. Intraspecific identifications such as fingerprinting methods - Restriction Fragment Length Polymorphism (RFLP) or Amplified Fragment Length Polymorphism (AFLP) - is used for more accurate identification of pathovars or races of bacteria, fungi or nematodes (Abeln et al., 2002; Cullen et al., 2007; Flores-Gonzalez et al., 2008; Pitman etal., 2008). Although not translated into proteins, the ITS (internal transcribed spacers) coding regions have a critical role in the development of functional rRNA, with sequence variations among species showing promise as signature regions for molecular assays (Gardes and Bruns, 1993). A widely used approach is to conduct PCR using oligonucleotide primers specific for the conserved flanking regions of the internally transcriber spacers (ITS) of the fungal rRNA gene (White et al., 1990). Our group used ITS region sequencing for identification of several fungal species including, Trichoderma (Gherbawy et al., 2004), Pythium (Gherbawy etal., 2005), Mucor and Rhizopus, (Gherbawy and Hussien, 2010). Using ITS region sequences, Fiers et al. (2010) studied diversity ofmicroorganisms associated with atypical superficial blemishes of potato tubers in France. They reported that the most represented fungi belonged to the genera Fusarium, Rhizoctonia, Alternaria, Penicillium and Clonostachys.

As far as we know there is no literature concerning mycobiota of potato blemishes in Saudi Arabia, therefore; this study aimed to isolate fungi associated with potato superficial blemishes, identify the fungal communities which could be associated with blemishes and detect their pathogenicity potentials against potato tubers.

\section{Experimantal}

Materials and Methods

Plant material. The potato tubers were collected from different markets in Al-Qasim region during the period from January to December 2011. Blemishes were observed and classified according to Fiers et al. (2010). The tubers were stored in paper bags at $4^{\circ} \mathrm{C}$ during several weeks until the start of the experiment.

Isolation of fungi. As previously published by Fiers et al. (2010) as follows; tubers were washed under running tap water, and air dried. A $6 \mathrm{~mm}$ diameter and $5 \mathrm{~mm}$ deep pieces were excised with a cork borer from the affected area of each tuber. The tubers surface was sterilized in $1 \%$ bleach for $15 \mathrm{~s}$ and rinsed three times in sterile water. Each tuber explant was dried on sterile paper and plated on potato dextrose agar (PDA). After 5 days of incubation at room temperature under natural light, fungal colonies developing from the plant material were identified by microscopic observations and purified at least twice by serial transfers on PDA.

Molecular identification of fungal isolates. For DNA extraction, all the collected fungal isolates were inoculated in tubes on PDA slants. Two $\mathrm{ml}$ of potato dextrose broth (PDB) poured into PDA tubes and vortexed to disperse the spores, and the spores-PDB mix poured into flasks containing $100 \mathrm{ml}$ of PDB. Flasks were incubated at room temperature without shaking for 2 to 3 days. The mycelium was harvested by filtration, frozen at $-80^{\circ} \mathrm{C}$ during $30 \mathrm{~min}$, lyophilized and stored at $-80^{\circ} \mathrm{C}$. The mycelium was ground in liquid nitrogen in a sterile mortar to obtain a mycelium powder. The DNA extracted from $20 \mathrm{mg}$ of mycelium powder using DNeasy plant mini kit. The DNA quantity and quality checked by electrophoresis on a $0.8 \%$ agarose gel revealed with ethidium bromide and visualized by UV trans-illumination. The internal transcribed spacer (ITS) region of the ribosomal DNA (rDNA) was amplified by PCR with the primers ITS1-F(CTTGGTCATTTAGAGGAAGTAA) and ITS4 (TCCTCCGCTTATTGATATGC) (Gardes and Bruns, 1993; White et al., 1990). PCR amplifications were performed in a final volume of $50 \mu \mathrm{l}$ by mixing $2 \mu \mathrm{l}$ of DNA 
with $0.5 \mu \mathrm{M}$ of each primer, $150 \mu \mathrm{M}$ of dNTP, $6 \mathrm{U}$ of Taq DNA polymerase and PCR reaction buffer. Amplification conducted in a thermal cycler with an initial denaturation of $3 \mathrm{~min}$ at $94^{\circ} \mathrm{C}$, followed by 35 cycles of $1 \mathrm{~min}$ at $94^{\circ} \mathrm{C}, 1 \mathrm{~min}$ at $50^{\circ} \mathrm{C}, 1 \mathrm{~min}$ at $72^{\circ} \mathrm{C}$, and a final extension of $10 \mathrm{~min}$ at $72^{\circ} \mathrm{C}$. Aliquots of PCR products checked by electrophoresis on a $1 \%$ agarose gel revealed with ethidium bromide and visualized by UV trans-illumination. The PCR products sequenced using primers ITS1-F and ITS4. For each PCR product, sequences from both strands assembled to produce a consensus sequence.

Identifications based on sequences. The sequence results were blasted against GenBank to identify the isolated fungi to species level.

Pathogenicity test for the selected strains. The procedure was performed according to Peters et al. (2008). The healthy potato tubers (Solanum tuberosum L.) were used in this experiment. Initially, tubers appearing healthy and uniform in size (100-120 g) were selected and washed to remove excess soil, surface sterilized in $0.5 \%$ sodium hypochlorite solution for $10 \mathrm{~min}$ and rinsed in 3 changes of sterile distilled water (Lui and Kushalappa, 2002; Lui et al., 2005) and then air dried. Then the tubers wounded with a cork borer with a diameter of $5 \mathrm{~mm}$ to a depth of $5 \mathrm{~mm}$ (Choiseul et al., 2007; Peters et al., 2008). An agar plug (5 mm diameter) containing active mycelium of Fusarium and Gibberella isolates extracted from the margin of a 3-day-old cultures grown on one fourth strength PDA and placed into the wound, which was subsequently sealed with the excised plug of tuber tissue. Three tubers used for each fungal strain. All the wounded potato tubers were wrapped in black polyethylene bags (Manici and Cerato, 1994; Lui and Kushalappa, 2002) and incubated in the dark at $20^{\circ} \mathrm{C}$ for 3 weeks. As a control, tubers were inoculated with an agar plug (one fourth strength PDA) only. Following incubation, tubers were cut longitudinally from the point of inoculation and the depth of internal necrosis was measured using electronic calipers. The depth of wound response in controls was also recorded for comparison. For each isolate where disease was expressed, a small tissue sample $(10 \times 5 \times 3 \mathrm{~mm})$ from an individual tuber was taken from the margin of the internal necrotic region with a sterile scalpel, surface sterilized in $0.6 \%$ sodium hypochlorite for $15 \mathrm{~s}$, rinsed twice in sterile distilled water, and blotted dry on sterile filter paper. Tissue pieces were then plated onto one fourth strength PDA amended with tetracycline $(0.05 \mathrm{~g} / \mathrm{l})$ and streptomycin sulfate $(0.1 \mathrm{~g} / \mathrm{l})$. Petri dishes were incubated in the dark at $22^{\circ} \mathrm{C}$ for $4-7$ days. Following incubation, hyphal tips from the margins of actively growing isolates were removed with a sterile probe and plated onto one fourth strength PDA to generate pure cultures (Peters et al., 2008).
Statistical analysis. Data were subjected to analysis of variance (ANOVA) using the Statistical Analysis System (SAS Institute, Inc., 1996). Means were separated by Duncan's multiple range test at $P<0.05$ level.

\section{Results and Discussion}

The collected tubers samples showed 4 different blemish types namely: corky cracks, enlarged lenticels, netted scab and polygonal lesions (Table I). Polygonal lesions were the most frequently observed blemish type (Table I). This result is in agreement with Fiers et al. (2010), as they recorded several blemish types in potato tubers. They reported that the polygonal lesions were the most recorded blemish type.

One hundred and sixty one fungal strains were collected from the different blemish types (Table I). Eighty four strains were associated with polygonal lesions, while 50 strains were associated with enlarged lenticels. On the other hand, 14 and 13 strains were associated with corky cracks and netted scab, respectively. Sequences from the internal transcribed spacer (ITS) region of the nuclear ribosomal DNA have been commonly used for the identification of fungi (Kõljalg et al., 2005; Naumann et al., 2007; Nilsson et al., 2008; Gherbawy and Hussien, 2010; Gherbawy et al., 2010). Using ITS1 and ITS4 primers, the isolated strains produced amplicons ranging from 460 to $549 \mathrm{bp}$. Fusarium and Gibberella species produced amplicon sizes ranging from 496 to $522 \mathrm{bp}$. Mirhendi et al. (2010) reported that the amplicon sizes of ITS region sequences in Fusarium species using ITS1 and ITS4 primers ranged from 535 to $566 \mathrm{bp}$. The sequence result of each strain was blasted against GenBank to confirm the identification. The accession numbers of the collected strainsareshown in Table II.

Thirty one species belonged to 19 genera were collected from the different types of blemish and identified from their ITS sequence (Table II). Fusarium, Penicillium, Ilyonectria, Alternaria and Rhizoctonia were the most common genera. They were represented by Fusarium oxysporum, Penicillium brevicompactum, P. chrysogenum, Ilyonectria radicicola, Alternaria alternata and Rhizoctonia solani. Fiers et al. (2010) reported that the most represented genera from different blemish types were Fusarium (80 strains), Rhizoctonia (68 strains), Alternaria (46 strains), Penicillium (33 strains), and Clonostachys (27 strains). The fungus $R$. solani was cited as well as being responsible for the formation of polygonal lesions. Woodhall et al. (2007) reported Rhizoctonia solani AG3 as causal agents for blemish in potato tubers. The fungus growing on the tuber surface would delay the growth of the underlying tissues, resulting in deformed tubers. The pattern of the lesions on the skin would be related to the 
Table I

Fungal species isolated from the different blemishes

\begin{tabular}{|c|c|c|c|c|c|}
\hline \multirow[b]{2}{*}{ Genera and species } & \multicolumn{5}{|c|}{ Blemishes } \\
\hline & $\begin{array}{c}\text { Polygonal } \\
\text { lesions }\end{array}$ & $\begin{array}{l}\text { Corky } \\
\text { cracks }\end{array}$ & $\begin{array}{l}\text { Enlarged } \\
\text { lenticels }\end{array}$ & $\begin{array}{l}\text { Netted } \\
\text { scab }\end{array}$ & Total \\
\hline Alternaria & 13 & - & 3 & 3 & 19 \\
\hline A. alternata & 10 & - & 3 & 3 & 16 \\
\hline A. arborescens & 1 & - & - & - & 1 \\
\hline A. longissima & 2 & - & - & - & 2 \\
\hline Aspergillus & 5 & - & - & - & 5 \\
\hline A. flavus & 2 & - & - & - & 2 \\
\hline A. niger & 3 & - & - & - & 3 \\
\hline Bionectria ochroleuca & 4 & 1 & 1 & - & 6 \\
\hline Boeremia exigua & 1 & - & 1 & 1 & 3 \\
\hline Chaetomium piluliferum & 3 & - & - & - & 3 \\
\hline Cladosporium cladosporioides & 1 & - & 2 & - & 3 \\
\hline Cylindrocarpon olidum & 2 & - & - & - & 2 \\
\hline Davidiella tassiana & - & 1 & - & - & 1 \\
\hline Fusarium & 12 & 6 & 10 & 2 & 30 \\
\hline F. oxysporum & 10 & 6 & 4 & 2 & 22 \\
\hline F. redolens & 2 & - & 2 & - & 4 \\
\hline F. solani & - & - & 4 & - & 4 \\
\hline Gibberella & 1 & - & 1 & - & 2 \\
\hline G. pulicaris & 1 & - & - & - & 1 \\
\hline G. zeae & - & - & 1 & - & 1 \\
\hline Gliomastix murmorum & 1 & - & - & - & 1 \\
\hline Ilyonectriaradicicola & 11 & 3 & 12 & - & 26 \\
\hline Mucor & 2 & - & 4 & 2 & 8 \\
\hline M. circenelloides & 1 & - & 4 & 1 & 6 \\
\hline M. hiemalis & 1 & - & - & 1 & 2 \\
\hline Penicillium & 11 & 3 & 12 & 3 & 29 \\
\hline P. brevicompactum & 7 & - & 2 & 3 & 12 \\
\hline P. chrysogenum & 2 & - & 10 & - & 12 \\
\hline P.purpurogenum & 1 & - & - & - & 1 \\
\hline P. swiecickii & 1 & 3 & - & - & 4 \\
\hline Rhizoctonia solani & 6 & - & 4 & 1 & 11 \\
\hline Rhizopus oryzae & 3 & - & - & - & 3 \\
\hline Trichoderma & 5 & - & - & 1 & 6 \\
\hline T. tomentosum & 2 & - & - & - & 2 \\
\hline T. velutinum & 3 & - & - & 1 & 4 \\
\hline Ulocladium & 2 & - & - & - & 2 \\
\hline U. capsicum & 1 & - & - & - & 1 \\
\hline U. atrum & 1 & - & - & - & 1 \\
\hline Verticillium dahliae & 1 & - & - & - & 1 \\
\hline Total & 84 & 14 & 50 & 13 & 161 \\
\hline
\end{tabular}

pattern of the branching hyphae of the fungus. Some of these hyphae may still be present on newly harvested tubers (Tsror., 2010). Fusarium oxysporum is one of the most frequently found Fusarium species on potato where it is more common in the wet and warm climate of Italy (Manici and Cerato, 1994). Also, Manici and Cerato (1994) andChehri et al. (2011) isolated Fusarium oxysporum as the one of the most common species isolated from potato tubers. Salami and Popoola (2007) isolated five pathogenic fungi viz: Botryodiplodia theo- 
Table II

Fungal strains collected from potato blemishes, their accession numbers and percentage of similarities with other GeneBank fungal species based on ITS region sequencing results.

\begin{tabular}{|c|c|c|c|c|c|}
\hline No & Strains & $\begin{array}{c}\text { Accession } \\
\text { numbers }\end{array}$ & Gene bank strains & Identities & Given names \\
\hline 1 & KAUF1 & HE649372 & Alternaria alternata JN604114 & $527 / 532(99 \%)$ & Alternaria alternate \\
\hline 2 & KAUF2 & HE649373 & Alternaria arborescens EU314991 & $455 / 460(99 \%)$ & Alternaria arborescens \\
\hline 3 & KAUF3 & HE649374 & Alternaria longissima DQ865104 & $523 / 530(99 \%)$ & Alternaria longissima \\
\hline 4 & KAUF4 & HE649375 & Aspergillus flavus JN252115 & $515 / 525(98 \%)$ & Aspergillus flavus \\
\hline 5 & KAUF5 & HE649376 & Aspergillus niger JF710186 & $511 / 511(100 \%)$ & Aspergillus niger \\
\hline 6 & KAUF6 & HE649377 & Chaetomium piluliferum AB625587 & $521 / 531(98 \%)$ & Chaetomium piluliferum \\
\hline 7 & KAUF7 & HE649378 & Cladosporium cladosporioides JN565298 & $525 / 534(98 \%)$ & Cladosporium cladosporioides \\
\hline 8 & KAUF8 & HE649379 & Davidiella tassiana GU566258 & $499 / 509(98 \%)$ & Davidiella tassiana \\
\hline 9 & KAUF9 & HE649380 & Bionectria ochroleuca FJ025201 & $533 / 543(98 \%)$ & Bionectria ochroleuca \\
\hline 10 & KAUF10 & HE649381 & Cylindrocarpon olidum GU198183 & $493 / 503(98 \%)$ & Cylindrocarpon olidum \\
\hline 11 & KAUF11 & HE649382 & Gibberella zeae JN942838 & $512 / 522(98 \%)$ & Gibberella zeae \\
\hline 12 & KAUF12 & HE649383 & Fusarium oxysporum JF807394 & $506 / 516(98 \%)$ & Fusarium oxysporum \\
\hline 13 & KAUF13 & HE649384 & Fusarium redolens DQ093672 & $486 / 496(98 \%)$ & Fusarium redolens \\
\hline 14 & KAUF14 & HE649385 & Gibberella pulicaris JN942835 & $500 / 509(98 \%)$ & Gibberella pulicaris \\
\hline 15 & KAUF15 & HE649386 & Fusarium solani JN168971 & $500 / 510(98 \%)$ & Fusarium solani \\
\hline 16 & KAUF16 & HE649387 & Gliomastix murorum HQ115690 & $520 / 530(98 \%)$ & Gliomastix murorum \\
\hline 17 & KAUF17 & HE649388 & Mucor hiemalis HM172832 & $523 / 531(98 \%)$ & Mucor hiemalis \\
\hline 18 & KAUF18 & HE649389 & Mucor circinelloides JN368455 & $520 / 531(98 \%)$ & Mucor circinelloides \\
\hline 19 & KAUF19 & HE649390 & Neonectria radicicola HQ840391 & $515 / 524(98 \%)$ & Ilyonectriaradicicola \\
\hline 20 & KAUF20 & HE649391 & Penicillium brevicompactum FJ884116 & $504 / 513(98 \%)$ & Penicillium brevicompactum \\
\hline 21 & KAUF21 & HE649392 & Penicillium chrysogenum JF731276 & $539 / 549(98 \%)$ & Penicillium chrysogenum \\
\hline 22 & KAUF22 & HE649393 & Penicillium purpurogenum HQ392494 & $523 / 532(98 \%)$ & Penicillium purpurogenum \\
\hline 23 & KAUF23 & HE649394 & Penicillium swiecickii GU441580 & $499 / 508(98 \%)$ & Penicillium swiecickii \\
\hline 24 & KAUF24 & HE649395 & Phoma exigua EU520200 & $504 / 514(98 \%)$ & Boeremia exigua \\
\hline 25 & KAUF25 & HE649396 & Rhizoctonia solani JN545836 & $461 / 470(98 \%)$ & Rhizoctonia solani \\
\hline 26 & KAUF26 & HE649397 & Rhizopus oryzae JN943054 & $524 / 534(98 \%)$ & Rhizopus oryzae \\
\hline 27 & KAUF27 & HE649398 & Trichoderma tomentosum JN628069 & $497 / 506(98 \%)$ & Trichoderma tomentosum \\
\hline 28 & KAUF28 & HE649399 & Trichoderma velutinum HQ115666 & $524 / 533(98 \%)$ & Trichoderma velutinum \\
\hline 29 & KAUF29 & HE649400 & Ulocladium capsicum AY762940 & $516 / 526(98 \%)$ & Ulocladium capsicum \\
\hline 30 & KAUF30 & HE649401 & Ulocladium atrum AY625072 & $535 / 544(98 \%)$ & Ulocladium atrum \\
\hline 31 & KAUF31 & HE649402 & Verticillium dahliae HQ206719 & $482 / 492(98 \%)$ & Verticillium dahliae \\
\hline
\end{tabular}

bromae, Fusarium redolens, Fusarium oxysporum, Penicillium sp. and Rhizopus oryzae associated with post harvest storage rot of root-tubers. In Turkey, Demirci et al. (2011) isolated several fungal species from potato tubers namely: Acremonium strictum, Alternaria alternata, Chaetomium sp., Cladosporium cladosporioides, Fusarium equiseti, F. oxysporum, F. solani, F. verticillioides, Gliocladium catenulatum, G. viride, Paecilomyces sp., P. marquandii, P. sulphurellus, Penicillium camemberti, P. expansum, P. frequentans, $P$. nigricans, P. olsonii, P. phialosporum, Plectosporium tabacinum, Sporothrix sp., Sporothrix schenckii, Trichoderma harzianum and Verticillium dahliae. Lydia et al. (2012) isolated Alternaria alternate and A. solani from potato leaves with lesions from the Pacific Northwest over several growing seasons. Cwalina-Ambroziak (2012) isolated 31 species of filamentous fungi, non-sporulating fungi, and yeast like fungi from stems of three potato cultivar in Poland and Alternaria alternate and Colletotrichum coccodes were the predominant species. The results of a field survey of potato fungal diseases for two successive years in the six main potato producing regions in the Kingdom of Saudi Arabia proved the presence of fifteen fungal genera (Al-Kherb et al., 1996). They isolated the following fungal genera, in descending order: Fusarium, Alternaria, Rhizoctonia, Stemphyllium, Cladosporium, Helminthosporium, Colletotrichum, Phytophthora, Pythium, Macrophomina, Phoma, Rosellinia, Verticillium, Cercospora and Sclerotium. They reported thatRhizoctonia solani was the most frequent on 
tubers, while Fusarium spp. were the most frequent on roots and stem bases.

Pathogenicity. During this work, five species of Fusarium and Gibberella were collected. These were: Fusarium oxysporum (4 strains), F. redolens (2), F. solani (1), Gibberellapulicaris = Fusarium sambucinum (1) and Gibberella zeae $=$ Fusarium graminearum (1). Dry rot of potato caused by Fusariumspecies is a common and commercially serious disease of potato tubers found in all production areas of the world (Nasr-Esfahani, 1998; Lui and Kushalappa, 2002; Slininger et al., 2004; Cullen et al., 2005 Chehri et al. 2011). Gashango et al. (2012) surveyed the seed potato tubers in Michigan seed production storage facilities during 2009 and 2010. They identified Fusarium spp. associated with tuber dry rot symptoms. They reported that, F. oxysporum was the most commonly isolated species (30.3\%), followed by F. equiseti (19.3\%). F. sambucinum and F.avenaceum were the third most prevalent (each at 13.6\%). The pathogenicty of the collected Fusarium isolates against potato tubers was studied. Variable degrees of pathogenicity were recorded with the collected Fusarium isolates (Table III). They ranged from highly pathogenic isolates: Gibberellapulicaris $($ KAUF14) $=$ Fusarium sambucinum, Gibberella zeae $(\mathrm{KUAF} 11)=$ Fusarium graminearum and Fusarium solani KAUF15). These results were in agreement with the results published by El-Hassan et al. (2007). They reported that Fusarium spp. isolates varied in their pathogenicity against potato tubers. They ranged from highly pathogenic like two isolates of Fusarium sambucinum, 6 isolates of F. solani and one isolate of F. oxysporum to totally

Table III

Pathogenicity, as measured by mean depth of necrosis (in mm), of 9 isolates of Fusarium and Gibberella spp. following wound inoculation of potato tubers.

\begin{tabular}{|l|l|c|c|}
\hline $\begin{array}{c}\text { Fusarium and } \\
\text { Gibberella species }\end{array}$ & Strain & $\begin{array}{c}\text { Depth of } \\
\text { necrosis }(\mathrm{mm})\end{array}$ & $\begin{array}{c}\text { Pathogenicity } \\
\text { rating }^{\mathrm{b}}\end{array}$ \\
\hline Control $^{\mathrm{a}}$ & - & $6.5^{\mathrm{c}}$ & $\mathrm{NP}$ \\
\hline Fusarium oxysporum & KAUF12.1 & $7.6^{\mathrm{c}}$ & $\mathrm{NP}$ \\
\hline Fusarium oxysporum & KAUF12.2 & $7.6^{\mathrm{c}}$ & $\mathrm{NP}$ \\
\hline Fusarium oxysporum & KAUF12.3 & $8.2^{\mathrm{c}}$ & $\mathrm{NP}$ \\
\hline Fusarium oxysporum & KAUF12.4 & $7.6^{\mathrm{c}}$ & $\mathrm{NP}$ \\
\hline Fusariumredolens & KAUF13.1 & $12.0^{\mathrm{d}}$ & $\mathrm{P}$ \\
\hline Fusariumredolens & KAUF13.2 & $12.1^{\mathrm{d}}$ & $\mathrm{P}$ \\
\hline Fusarium solani & KAUF15 & $16.5^{\mathrm{d}}$ & $\mathrm{P}$ \\
\hline Gibberellapulicaris & KAUF14 & $23.2^{\mathrm{e}}$ & $\mathrm{P}$ \\
\hline Gibberella zeae & KAUF11 & $18.2^{\mathrm{d}}$ & $\mathrm{P}$ \\
\hline
\end{tabular}

${ }^{a}$ Control tubers were wounded and inoculated with an agar plug (5 mm diameter) of potato dextrose only (no fungal mycelium). ${ }^{b}$ Pathogenicity rating; $\mathrm{NP}=$ non pathogenic and $\mathrm{P}=$ pathogenic. Values with the same letters in each column are not significantly different at $\mathrm{P}=0.05$. nonpathogenic isolates like 5 isolates of $F$. sambucinum, 3 isolates of F. oxysporum, one isolates of F. culmorum, 2 isolates of F. equiseti and one isolate of F. semitectum. Peters et al. (2008) recorded that Fusarium sambucinum, Fusarium graminearum and Fusarium graminearum were listed among the most pathogenic fungi to potato tubers. Fusarium sambucinum is the most common Fusarium dry rot pathogen in North America and Europe, although other Fusarium spp. have been also reported (Secor and Salas, 2001; Peters et al., 2008; Delgado et al., 2010). The natural occurrence of Fusarium dry rot caused by $F$. graminearum(teleomorph Gibberella zeae) was reported in 2005 in naturally infected, commercially stored potato tubers in North Dakota and Minnesota (Ali et al., 2005). Estrada et al. (2010) surveyed the stored potato tubers affected by Fusarium dry rot (FDR) from commercial storage facilities during 2004-05. They determined that $58 \%$ of the Fusarium spp. isolated was F. sambucinum, and $42 \%$ was F. graminearum.

Fusarium redolens represented by two strains (KAUF13.1 and KAUF13.2) showed moderate pathogencity according to the measurement of depth of necrosis. Fusarium oxysporum strains KAUF12.1, KAUF12.2, KAUF12.3 and KAUF12.4 did not show any pathogenicity against tubers (Table 3 ). Salami and Popoola (2007) reported that Fusarium redolens and Botryodiplodia theobromae were the most aggressive and virulent to potato tubers, followed by Rhizopus oryzae and Fusarium oxysporumwhile Penicillium species was the least pathogenic. Also, Peters et al. (2008) tested 3 strains of F. oxysorum isolated from potato against potato tuber, all strains were non-pathogenic. A study done by Song et al. (2008) also cited that F. oxysporum is the predominant species causing dry rot. Chehri et al. (2011) in Malaysia studied the occurrence and pathogenicity of Fusarium spp. on potato tubers. Their results of the pathogenicity test revealed that F. solani isolates FSO4, FSO12, FSO18 and F. oxysporum isolates FOX4 and FOX16 were strongly pathogenic to theinoculated potato tubers.

In conclusion, polygonal lesions werethe most frequently observed blemish type in Saudi potato tubers. Fusarium was the most prevalent genus among fungal genera associated with potato tuber blemish in Saudi Arabia. The collected Fusarium species showed variable degrees of pathogenicity against potato tubers.

\section{Acknowledgement}

This work was supported by a grant (Contract No. 1431-363-430) from King Abdulaziz University, Kingdom of Saudi Arabia. The authors are very grateful for the deanship of scientific research at King Abdulaziz and for the financial support they received. The authors express their gratitude to prof. dr Gary Strobel (Department of Plant Science, Montana State University) for English revision of the manuscript. 


\section{Literature}

Abeln E.C.A., A.M. Stax, J. de Gruyter and H.A. van der Aa. 2002. Genetic differentiation of Phoma exigua varieties by means of AFLP fingerprints. Mycol. Res. 106: 419-427.

AI-Kherb S.M., Z.M. Abul-Hayja and I.M. AI-Shahwan. 1996. Potato Fungal Diseases in the Kingdom of Saudi Arabia. Journal of King Saud University. Agricultural Sciences 8: 147-156.

Ali S., V.V. Rivera and G.A. Secor. 2005. First report of Fusarium graminearum causing dry rot of potato in North Dakota. Plant. Dis. 89: 105.

Boyd A.K.W. 1972. Potato Storage Diseases. Rev. Plant Pathol. 51: 297-321.

Chehri K., N.F. Mohamed, B. Salleh and Z. Latiffah. 2011. Occurrence and pathogenicity of Fusarium spp. on the potato tubers in Malaysia. African J. Agric. Res. 6: 3706-3712.

Chelkowski J. 1989. Toxinogenic of Fusarium species causing dry rot of potato tubers. In: Chelkowski J. (Ed.), Fusarium Mycotoxin, Taxonomy and Pathogenicity. Elsevier Publishing Co., New York, pp. 435-440.

Choiseul J., L. Allen, S.F. Carnegie. 2007. Fungi causing dry tuber rots of seed potatoes in storage in scotland. Potato Res. 49: 241-253. Cullen D.W., I.K. Toth, N. Boonham, K. Walsh, I. Barker and A.K. Lees. 2007. Development and validation of conventional and quantitative polymerase chain reaction assays for the detection of storage rot potato pathogens, Phytophthora erythroseptica, Pythium ultimum and Phoma foveata. Journal of Phytopathology. 155: 309-315.

Cullen D.W., I.K. Toth, Y. Pitkin, N. Boonham, K. Walsh, I. Barker, and A.K. Lees. 2005. Use of quantitative molecular diagnostic assays to investigate Fusarium dry rot in potato stocks and soil. Phytopathology 95: 1462-1471.

Cwalina-Ambroziak B. 2012. The effect of foliar fertilizers on mycelial growth of select pathogenic fungi under in vitro conditions. Pol. J. Environ. Stud. 21: 589-594.

Delgado J.A., P.B. Schwarz, J. Gillespie, V.V. Rivera-Varas and G.A. Secor. 2010. Trichothecene mycotoxins associated with potato dry rot caused by Fusarium graminearum. Phytopathology 100: 290-296.

Demirci E., E. Dane and C. Eken. 2011. In vitro antagonistic activity of fungi isolated from sclerotia on potato tubers against Rhizoctonia solani. Turk. J. Biol. 35: 457-462.

El-Hassan K.I., M.G. El-Saman, A.A. Mosa and M.H. Mostafa 2007. Variation among Fusarium spp. the causal of potato tuber dry rot in their pathogenicity and mycotoxins production. Egypt. J. Phytopathol. 35: 53-68

Eken C., E. Demirci and F. Sahin. 2000. Pathogenicity of the fungi determined on tubers from potato storages in Erzurum, Turkey. Journal of Turkish Phytopathology 29: 61-69.

Estrada R., N.C. Gudmestad, V.V. Rivera and G.A. Secor. 2010. Fusarium graminearumas a dry rot pathogen of potato: Prevalence, aggressiveness and factors affecting etiology. Plant. Pathol. 59: 1114-1112.

Fiers M., C. Chatot, V. Edel-Hermann, Y. Le Hingrat, A. Yanougo Konate, N. Gautheron, E. Guillery, C. Alabouvette and C. Steinberg. 2010. Diversity of microorganisms associated with atypical superficial blemishes of potato tubers and pathogenicity assessment. Eur. J. Plant Pathol. 128:353-371.

Flores-Gonzalez R., I. Velasco and F. Montes. 2008. Detection and characterization of Streptomyces causing potato common scab in Western Europe. Plant Pathology. 57:162-169.

Gachango E., L. Hanson, A. Rojas, J. Hao and W. Kirk. 2012. Fusarium spp. Causing dry rot of seed potato tubers in Michigan and their sensitivity to fungicides. Plant Disease http://dx.doi. org/10.1094/PDIS-11-11-0932-RE
Gardes M. and T.D. Bruns. 1993. ITS primers with enhanced specificity for Basidiomycetes - Application to the identification of mycorrhizae and rusts. Molecular Ecology. 2:113-118.

Gherbawy Y. and N. Hussien. 2010. Molecular characterization for Mucor circinelloides and Rhizopus stolonifer strains isolated from some Saudifruits. Journal of Foodborne pathogens and disease 7: 137-142.

Gherbawy Y., H.M.A. Abdelzaher, J. Meens and H. El-Hariry. 2005. Morphological and molecular identification of some closely related Pythium species in Egypt. Archives of Phytopathology and Plant Protection 38: 193-208.

Gherbawy Y., I. Druzhinina, G.M. Shaban, M. Wuczkowski, M. Yaser, M.A. El-Naghy, H. Prillinger and C.P. Kubicek. 2004. Trichoderma populations from alkaline agricultural soil in the Nile valley, Egypt, display an unusual poor biodiversity. Mycological progress 3: 211-218.

Gherbawy Y., C. Kesselboth, H. Elhariry and K. Hoffmann. 2010. Molecular barcoding of microscopic fungi with emphasis on the mucoralean genera Mucor and Rhizopus (2010): In: Gherbawy Y. and Voigt K. (eds.) Molecular identification of fungi. Springer Verlag, Berlin, Heidelberg, New York. p. 213-250.

Gudmestad N.C., R.J. Taylor and J.S. Pasche. 2007. Management of soilborne diseases of potato. Australasian Plant Pathology. 36: 109-115.

Hide G.A.,P.J. Read and S.M. Hall. 1992. Resistance to thiabendazole in Fusarium species isolated from potato tubers affected by dry rot. Plant Pathol. 41:745-748.

Kõljalg U., K.H. Larsson, K. Abarenkov, R.H. Nilsson, I.J. Alexander, U. Eberhardt, S. Erland, K. Høiland, R. Kjøller and E. Larsson. 2005. UNITE: a database providing web-based methods for the molecularidentification of ectomycorrhizal fungi. New Phytologist 166:1063-1068.

Lui L.H. and A.C. Kushalappa. 2002. Response surface models to predict potato tuber infection by $F$ sambucinum from duration of wetness and temperature, and dry rot lesion expansion from storage time and temperature. Int. J. Food Microbiol. 76, 19-25.

Lui L.H., A. Vikram, Y. Abu-Nada, A.C. Kushalappa, G.S.V. Raghavan and K. Al Mughrabi. 2005. Volatile metabolic profiling for discrimination of potato tubers inoculated with dry and soft rot pathogen. Am. J. Potato Res. 82:1-8.

Lydia S.T., D.A. Johnson and T.F. Cummings. 2012. The effects of wounding and potato cultivar on pathogenicity and aggressiveness of Alternaria solani and A. alternata 39-45. Proceedings of the Washington-Oregon Potato Conference January 24-26, 2012. Kennewick, Washington. http://www.potatoes.com/IPMStuff/PDFs/ Proceedings2012.pdf

Manici L.M. and C. Cerato. 1994. Pathogenecity of Fusarium oxysporum f. sp. tuberosi isolates from tubers and potato plants. Potato Res. 37: 129-134.

Mirhendi H., A. Ghiasian, H.F. Vismer, M.R. Asgary, N. Jalalizand, M.C. Arendrup and K. Makimura. 2010. Preliminary identification and typing of pathogenic and toxigenic Fusarium species using restriction digestion of ITS1-5.8S rDNA-ITS2 region. Iranian. J. Publ. Health. 39: 35-44.

Nasr-Esfahani M. 1998. Fusarium species associated with dry rot of potato tubers in Esfahan. Iran. J. Plant Pathol. 34: 225-232. Nauman A., M. Navarro-González, O. Sánchez-Hernández, P.J. Hoegger and U. Kües. 2007. Correct identification of woodinhabiting fungi by ITS analysis. Current Trends in Biotechnology and Pharmacy 1: 41-61.

Nilsson R.H., E. Kristiansson, M. Ryberg, N. Hallenberg and K.H. Larsson. 2008. Intraspecific ITS variability in the kingdom Fungi as expressed in the international sequence databases and its implications for molecular species identification. Evolutionary Bioinformatics 4: 193-201. 
Peters J.C., A.K. Lees, D.W. Cullen, L. Sullivan, G.P. Stroud and A.C. Cunnington. 2008. Characterization ofFusarium spp. responsible for causing dry rot of potato in Great Britain. Plant Pathol. 57: 262-271.

Pitman A.R., P.J. Wright, M.D. Galbraith and S.A. Harrow. 2008 Biochemical and genetic diversity of pectolytic enterobacteria causing soft rot disease of potatoes in New Zealand. Australasian Plant Pathology 37: 559-568.

Salami A.O. and O.O. Popoola. 2007. Thermal control of some post-harvest rot pathogens of Irish potato (Solanum tuberosum L). Journal of Agricultural Sciences 52: 17-31.

SAS Institute, Inc. 1996. SAS/STAT User's Guide, Version 6, $12^{\text {th }}$ ed. Vol. 2, 846 pp. SAS Institute, Inc. Cary, North Carolina, USA. Satyaprasad K., G.L. Bateman and P.J. Read. 1997. Variation in pathogenicity on potato tubers and sensitivity to thiabendazole of the dry rot fungus Fusarium avenaceum. Potato Res. 40: 357-366. Schisler D.A. and P.J. Slininger. 1994. Selection and performance of bacterial strains for biologically controlling Fusarium dry rot of potatoes incited by Giberalla pulicaris. Plant Disease 78: 251-255.

Schisler D.A., P.J. Slininger and R.J. Bothast. 1997. Effects of antagonists cell concentration and two-strain mixtures on biological control of Fusarium dry rot of potatoes. Phytopathology 87: 177-183. Secor G.A. and B. Salas. 2001. Fusarium dry rot and fusarium wilt. In: Compendium of potato diseases, eds. W.R. Stevenson, R. Loria, G.D. Franc, and D.P. Weingartner, 23-25. St. Paul, MN, USA: APS Press.
Senter L.H., D.R. Sanson, D.G. Corley, M.S. Tempesta, A.A. Rottinghaus and G.E. Rottinghaus. 1991. Cytotoxicity of trichothecene mycotoxins isolated from Fusarium sporotrichioides (MC-72083) and Fusarium sambucinum in baby hamster kidney (BHK-21) cells. Mycopathologia 113:127-131.

Slininger P.J., K.D. Burkhead and A.D. Schisler. 2004. Antifungal and sprout regulatory bioactivities of phenylacetic acid, indole3-acetic acid and tyrosol isolated from the potato dry rot suppressive Bacterium Enterobacter cloacae S11: T:07. J. Ind. Microbiol. Biotechnol. 31: 517-524.

Song H., H. Lee, J. Jeong, H. Park and C. Lee. 2008. Diversity in beauvericin and enniatins $\mathrm{H}$, I and MK1688 by Fusarium oxysporum isolated from potato. Int. J. Food Microbiol. 122: 296-301.

Tivoli B., A. Deltour, D. Molet, P. Bedin and B. Jouan. 1986. Isolation of thiabendazole resistant strains of Fusarium roseum var. sambucinum from potato tubers. Agronomie 6: 219-224.

Tsror L. 2010. Biology, epidemiology and management of Rhizoctonia solani on Potato. J. Phytopathol. 158: 649-658.

White T.J., T. Bruns, S. Lee and J. Taylor. 1990. Amplification and direct sequencing of fungal ribosomal RNA genes for phylogenetics. In: Innis M.A., Gelfand D.H., Sninsky J.J. and White T.J., eds. PCR protocols. A Guide to Methods and Applications. San Diego: Academic Press: ed. 315-322.

Woodhall J.W., A.K. Lees, S.G. Edwards and P. Jenkinson. 2007. Characterization of Rhizoctonia solani from potato in Great Britain. Plant Pathol. 56: 286-295. 